\title{
Do Exports lead Economic Output in Five Asian Countries? A Cointegration and Granger Causality Analysis
}

\author{
Jiayi Huang and Miguel D. Ramirez \\ Department of Economics, Trinity College, Hartford, CT 06106
}

Received: June 7, 2016 Accepted: June 23, 2016

doi:10.5296/ber.v6i2.9747ＵRL: http://dx.doi.org/10.5296/ber.v6i2.9747

\begin{abstract}
This paper examines the relationship between exports and economic output for five major Asian economies using annual data in an expanded data set and employing unit root and cointegration analysis. It employs a Vector Error Correction Model (VECM) that treats all variables in the modified production function as potentially endogenous and then determines via weak exogeneity tests whether some of the key variables can be treated as exogenous (omitted from the system). Johansen cointegration tests find a positive long-run relationship between exports and economic output for the Philippines, Singapore, and Thailand. Cointegration tests find a negative long-run relationship between exports and economic output for India. The Block Granger causality tests and impulse response functions for the Philippines and Singapore find stronger causality from exports to economic output rather than the reverse. Granger causality tests in level form also find significant causality from exports to economic output. No causality exists between exports and economic output in the case of India. Exports seem to promote economic growth in three of the four countries that have cointegrated data, which supports the exports-led growth hypothesis found in some of the extant literature. The paper does not find cointegration for China because the variables are integrated of different orders from $\mathrm{I}(0)$ to $\mathrm{I}(2)$.
\end{abstract}

Keywords: Block Granger Causality Test, Export-led Growth Hypothesis, Johansen Cointegration Test, Modified Production Function, Pantula Procedure, Phillips-Perron Test, Vector Error Correction Model (VECM), Zivot-Andrews single-break unit root test.

JEL: C22, F14, \& 053 


\section{Introduction}

With the advent of increasing globalization and world trade, there is an ongoing debate on the relationship between exports and economic output. Earlier empirical studies (Balassa, 1985; Chow, 1987; Feder, 1983; Ram, 1987; Sengupta \& Espana, 1994) find many beneficial effects of exports on economic growth. Exports can utilize excess capacity, increase specialization, and generate economies of scale. The import of capital goods, technology, and managerial skills can generate spillover effects on non-export sectors. Modern trade theory suggests that every country has its comparative advantage regardless of its absolute productivity and should benefit from exporting goods the production of which is intensive in the relatively abundant factor. In the 1980s the "four Asian tigers" (Hong Kong, Singapore, South Korea, and Taiwan) emerged as fast-growing economies led by export promotion strategies. Since 2001 China has become a "world factory" and its nominal GDP is now second only to the United States. However, export promotion has short-run costs such as job losses and income redistribution in import-competing industries; it is also important to note that export composition is an important factor in stimulating economic growth. Manufacturing exports are often associated with the greatest transfer of technological know-how while exports of natural resources may bring a "resource curse" (Perkins et al., 2013).

Recent studies have applied Granger causality and cointegration tests to examine the debate more accurately. Ghatek et al. (1997) find that aggregate exports, driven by manufacturing exports, "Granger cause" GDP and non-export GDP in Malaysia from 1955 to 1990. Mah (2007) finds cointegration and bi-directional causality between economic growth and export expansions in China during the period 1980-2001. Koh and Mah (2013) find bi-directional causality between export composition and economic growth in South Korea from 1970 to 2007, while a higher ratio of non-textile to textile exports promotes economic growth. Other papers (Thornton, 1996; Islam, 1998; Awokuse, 2005) study the relationship between exports and economic output without decomposing exports. Due to the relatively limited number of (annual) observations in this paper, it does not introduce the manufacturing exports variable but examines the relationship between aggregate exports and economic output.

\section{Theoretical Model}

Following the lead of Vohra (2001), this paper analyzes the relationship between exports and economic output using annual data for five Asian countries: India (1981-2014), Philippines (1983-2014), Singapore (1982-2014), Thailand (1980-2014), and China (1982-2014). ${ }^{1}$ The sample period depends on the data availability for the economically active population (EAP). The paper uses the EAP from the International Labor Organization rather than the whole population to approximate the labor force more accurately. ${ }^{2}$ The EAP may still not be the best

\footnotetext{
${ }^{1}$ The range of observations fluctuates between 32 and 35 years which is sufficient to invoke the Central Limit Theorem, but below the threshold level of 50 observations recommended by Granger and Newbold (see Charemza and Deadman, 1997). However, Maddala and Kim (1998) argue that,provided a threshold level of 30 observations is attained, the power of the unit root and cointegration tests depends more on the time span rather than the number of observations per se; i.e., unit root tests based on 35 observations over a span of 35 years may have more power than ones based on 100 observations over 100 days. ${ }^{2}$ Economically active population (EAP) includes all people who can possibly supply labor to the production of goods and services in a country. Detailed calculation and data (1980-2020) can be accessed at
} 
measure of the labor force since it assumes a constant labor force participation rate (LFPR). The LFPR provided by the World Bank only goes back to 1990 which would result in too few observations for meaningful regressions. In Figure 1 the LFPR of the five countries has gradually fallen since 1990 . The empirical model for each country is:

$$
L R G D P_{t}=\beta_{0}+\beta_{1} L K_{t}+\beta_{2} L E A P_{t}+\beta_{3} L X_{t}+e_{t}
$$

LRGDP, LK, LEAP, and LX are logarithms of real GDP, real gross capital formation, EAP, and real exports. The logarithmic transformation is used to linearize any exponential trend in the macroeconomic series and to provide direct interpretations of the estimated coefficients as elasticities. All variables except EAP are collected from the World Development Indicator of the World Bank. ${ }^{3}$ As part of the aggregate production function, gross capital formation approximates the capital stock due to the lack of available data. ${ }^{4}$ As opposed to Vohra's study, this paper replaces Malaysia and Pakistan with Singapore and China while keeping the other three countries the same for comparability with her findings. Pakistan is replaced with China because China has become a leading exporter and experienced unprecedented economic growth since it joined the World Trade Organization in 2001. Malaysia is replaced with Singapore because the EAP data for Malaysia only goes back to $1988 .{ }^{5}$ Singapore may not represent the experiences of larger countries given its special status as a city state. Figure 2 shows that the population of Malaysia has a similar (but steeper) upward trend as the EAP.

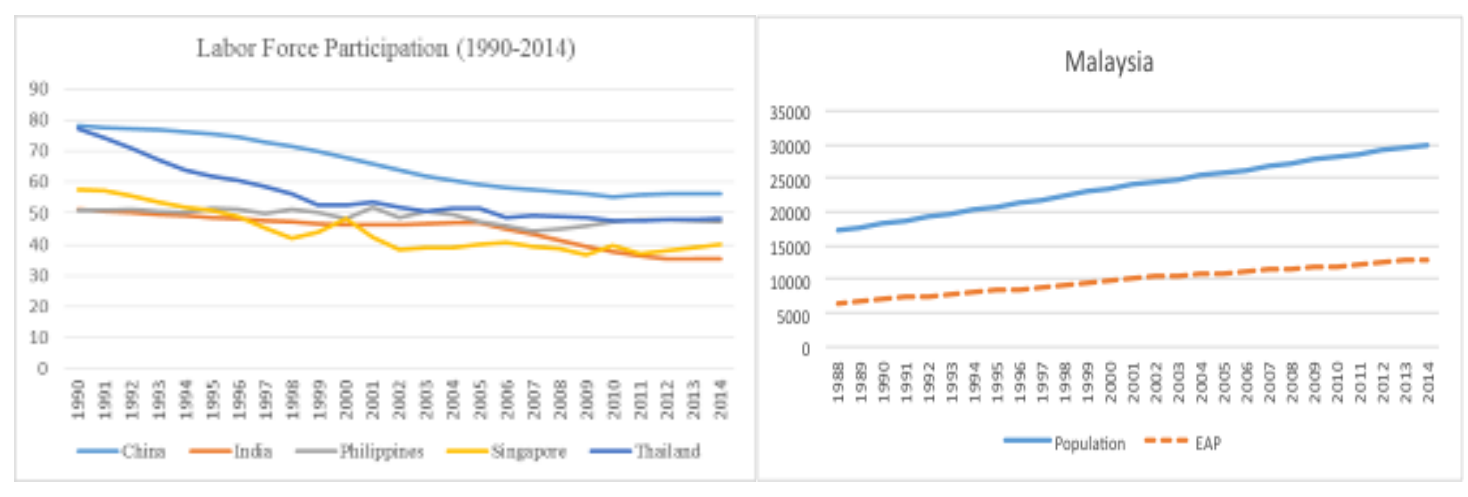

Figure $1 \& 2$. Labor Force Participation in Five Countries and Population in Malaysia

While Vohra (2001) tests for unit roots and cointegration with ADF tests and the original Engle-Granger approach, respectively, this paper applies high-powered unit root tests and the Johansen cointegration method to updated data. The unit root tests include the Phillips-Perron (1988), Kwiatkowski-Phillips-Schmidt-Shin (1992), and Zivot-Andrews (1992) single-break tests. Compared with the ADF tests, the PP tests allow for less restrictive error terms and the confirmatory KPSS tests use stationarity as its null hypothesis. The Doldado-Sosvilla (1990)

\footnotetext{
http://laborsta.ilo.org/applv8/data/EAPEP/eapep_E.html.

${ }^{3}$ http://databank.worldbank.org/data/reports.aspx?source=world-development-indicators\#. Real terms are measured in 2005 US dollars.

${ }^{4}$ It is possible to calculate the capital stock from investment flows using a perpetual inventory model and depreciation rate, but the data for depreciation rate are not available and national estimates may not be accurate. However, using gross capital formation assumes a constant capital-output ratio which may not be realistic.

${ }^{5}$ Malaysia is an influential and representative country in Southeast Asia, which the sample should have included given enough data.
} 
procedure systematically determines whether to include an intercept and/or a deterministic trend into the specification of the test equation. The Zivot-Andrews tests are the most conservative among the four tests and account for one endogenously-determined break. The power of Zivot-Andrews tests are maximized when model $\mathrm{C}$ (with an intercept and trend) is used and the loss of its power is minimized even if model C is not true (Sen, 2003). The Zivot-Andrews tests are conducted with one lag. The Johansen approach outperforms the Engle-Granger approach because it is capable of determining the number of cointegrating vectors for any given number of non-stationary series (of the same order). The original Engle-Granger approach also relies on a two-step estimator in which any error in generating the residuals is carried into the second step. Finally, Vohra (2001) ignores the potential problem of reverse causation from economic growth to exports, so this paper applies Granger causality tests to the variables if cointegration exists. Integrated series cannot cause one another in the long run unless they are cointegrated. Causality in econometrics indicates the ability of one variable to predict and therefore "cause" the other variable (Granger, 1969).

For each country, the paper first runs unit root tests to find the order of cointegration for all variables. When the variables are $\mathrm{I}(1)$ or a mix of $\mathrm{I}(1)$ and $\mathrm{I}(0)$, the paper estimates a VAR model in level form to find the optimal lag with the SBC criterion before the Johansen test is applied. The underlying relationship varies across the five countries. The paper finds a unique cointegrating vector for Philippines and Singapore, so it proceeds to run the VECM model and weak exogeneity tests. Block causality tests and impulse response functions are also estimated to determine the direction and strength of the interactions among variables. The paper finds two cointegrating vectors for India and three cointegrating vectors for Thailand, so it determines the long-run relationship based on economic theory and the statistical significance of the estimated coefficients. Pairwise causality tests are conducted in level form, since it is much more difficult to interpret the VECM model with over two cointegrating vectors. The paper does not find cointegration for China because the variables are integrated of different orders from I(0) to I(2). The following section examines the results for each country.

\section{Country Studies}

\subsection{Philippines}

\subsubsection{Unit Root Tests And Johansen Cointegration}

The plots of the variables in Figure 3 indicate that all variables have upward trends and may be non-stationary. In Table 1 the four unit root tests generally return consistent results except for LRGDP. The KPSS test concludes at the 1\% that LRGDP is non-stationary contrary to the other tests. The conservative Zivot-Andrews test concludes at the $1 \%$ that in level form it is stationary, so LRGDP is probably I(0). LK is I(0) while LEAP and LX are I(1). The first three tests do not reach a consensus on whether LEAP and LX have a trend in their unit roots. 


\section{MInstitute Macrothink}

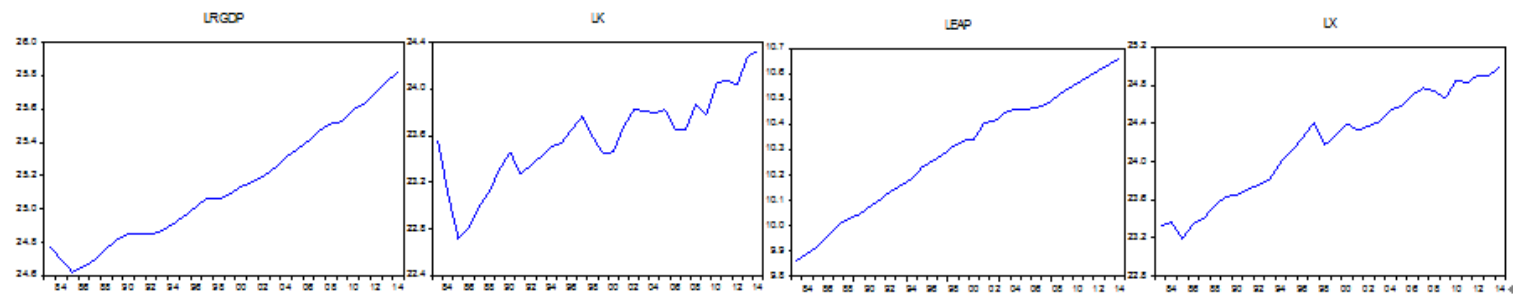

Figure 3. Plots of the Variables for Philippines (1983-2014)

Table 1. Stationarity Tests for Philippines

\begin{tabular}{|l|l|l|l|l|l|l|l|l|}
\hline & \multicolumn{4}{|l|}{ Level data } & \multicolumn{4}{l|}{ First difference } \\
\cline { 2 - 10 } & ADF & PP & KPSS & ZA & ADF & PP & KPSS & ZA \\
\hline LRGDP & $-3.86^{*}$ & $-3.64^{*}$ & $0.22^{* *}$ & $-6.58^{* *}$ & & & 0.09 & \\
\hline LK & $-4.26^{*}$ & $-4.30^{* *}$ & 0.06 & $-5.54^{*}$ & & & & \\
\hline LEAP & -1.78 & -2.00 & $0.18^{*}$ & -4.63 & $-6.29^{* *}$ & $-6.29^{* *}$ & 0.06 & $-7.44^{* *}$ \\
\hline LX & -2.72 & -2.73 & $0.16^{*}$ & -5.00 & $-6.68^{* *}$ & $-7.46^{* *}$ & 0.11 & $-6.94^{* *}$ \\
\hline
\end{tabular}

$* 5 \%$ significance and $* * 1 \%$ significance.

The paper estimates a Vector autoregressive model with up to 4 lags for the annual data and the Schwarz Bayesian Criterion (SBC) in Table 2 shows that 1 lag is optimal. The SBC penalizes model complexity most heavily, so the paper uses 1 lag (although AIC and FPE suggest 4 lags). Cointegration may exist among the three $\mathrm{I}(1)$ and one $\mathrm{I}(0)$ variables. The Johansen and Juselius (1990) method is applied with the Pantula procedure to determine whether there is a stable long-term relationship. Johansen tests can be run on five models with different specifications of the intercept and trend in the Cointegrating Equation (CE) and VAR. The paper only considers Models 2 to 4 in Table 3 since Models 1 and 5 are unrealistic (see Asteriou and Hall, 2016). In Table 4 the Pantula procedure estimates all models and evaluates the statistics from the most restrictive hypothesis (rank = number of cointegrating vectors $=0$ and model 2 ) to the least restrictive one ( $\mathrm{rank}=2$ and model 4 ). The procedure is halted when the null hypothesis of no cointegration cannot be rejected for the first time, and the previous model is then chosen. Although in small samples the Max-Eigen statistics are more powerful than trace statistics, the two statistics both suggest model 2 which only has an intercept in the CE. The Max-Eigen statistic indicates a unique cointegration vector and thus a VECM is generated in Table 5. The serial correlation LM tests and White heteroskedasticity tests indicate white-noise residuals. The cointegrating equation is normalized on LRGDP and the signs of the other three variables are thus reversed. The long-run estimates of LX and LK are positive while the estimate of LEAP is negative. The coefficients of all variables appear significant at the 5\% and the constant is insignificant which may suggest little bias of omitted variables. The coefficients appear unusually large. In the long run exports and capital promote economic output, but it seems unexpected that the EAP is negatively correlated with economic output. Perhaps, as living standards increase, families may have fewer kids and thus contribute to the decline of labor. 
Table 2. VAR Lag Criteria for Philippines

\begin{tabular}{|l|l|l|l|l|l|l|}
\hline Lag & LogL & LR & FPE & AIC & SC & HQ \\
\hline 0 & 87.08 & NA & $3.11 \mathrm{e}-08$ & -5.93 & -5.74 & -5.88 \\
\hline 1 & 229.88 & $234.61^{*}$ & $3.68 \mathrm{e}-12$ & -14.99 & $-14.04^{*}$ & -14.70 \\
\hline 2 & 247.24 & 23.56 & $3.62 \mathrm{e}-12$ & -15.09 & -13.38 & -14.57 \\
\hline 3 & 267.36 & 21.56 & $3.33 \mathrm{e}-12$ & -15.38 & -12.91 & -14.63 \\
\hline 4 & 290.61 & 18.27 & $3.18 \mathrm{e}-12^{*}$ & $-15.90^{*}$ & -12.67 & $-14.91^{*}$ \\
\hline
\end{tabular}

* indicates lag order selected by the criterion

Table 3. Intercept and Trend Specifications of Models 2-4

\begin{tabular}{|l|l|l|}
\hline & CE & VAR \\
\hline Model 2 & Intercept & No \\
\hline Model 3 & Intercept & Intercept \\
\hline Model 4 & Intercept, linear trend & Intercept \\
\hline
\end{tabular}

Table 4. Johansen Tests for Philippines

\begin{tabular}{|c|c|c|c|c|c|c|c|}
\hline \multicolumn{4}{|c|}{ Trace statistics } & \multicolumn{4}{|c|}{ Max-Eigen statistics } \\
\hline Rank & Model 2 & Model 3 & Model 4 & Rank & Model 2 & Model 3 & Model 4 \\
\hline 0 & $80.04 *$ & 45.17 & $67.51 *$ & 0 & $40.15^{*}$ & 25.02 & $34.95 *$ \\
\hline 1 & $39.89 *$ & 20.15 & 32.57 & 1 & 20.37 & 13.59 & 18.21 \\
\hline 2 & 19.52 & 6.56 & 14.36 & 2 & 13.58 & 6.23 & 10.13 \\
\hline
\end{tabular}

*indicates the statistic is significant at $5 \%$.

Table 5. VECM for Philippines

\begin{tabular}{|c|c|c|c|c|}
\hline \multicolumn{5}{|c|}{ Normalized Cointegration Coefficients } \\
\hline LRGDP & LK & LEAP & LX & C \\
\hline \multirow[t]{2}{*}{1.000000} & -172.8905 & 1190.376 & -379.6678 & 8705.2275 \\
\hline & {$[-1.79]$} & {$[3.30]$} & {$[-2.42]$} & {$[0.67]$} \\
\hline \multicolumn{5}{|l|}{ Error Correction Table } \\
\hline & D(LRGDP) & $\mathrm{D}(\mathrm{LK})$ & $\mathrm{D}(\mathrm{LEAP})$ & $\mathrm{D}(\mathrm{LX})$ \\
\hline Error correction coefficient & $3.87 \mathrm{E}-05$ & 0.000627 & 7-0.000116 & 0.000143 \\
\hline t-statistics & {$[0.86]$} & {$[2.44]$} & {$[-4.47]$} & {$[0.74]$} \\
\hline R-squared & 0.4821 & 0.2969 & 0.1090 & 0.1219 \\
\hline Adj. R-squared & 0.3992 & 0.1844 & -0.0336 & -0.0186 \\
\hline Akaike AIC & -4.5287 & -1.0368 & -5.6294 & -1.6156 \\
\hline Schwarz SC & -4.2952 & -0.8032 & -5.3959 & -1.3821 \\
\hline
\end{tabular}

\subsubsection{Vector Error Correction Model}

The VECM treats all variables as endogenous without initial assumption of causality and measures their short-run adjustments to the long-run equilibrium. Among the four variables LK and LEAP show significant adjustment coefficients but both coefficients are extremely small. The adjustment coefficient of $\mathrm{D}(\mathrm{LK})$ is significantly positive and a $10 \%$ shock last year pushes capital away from the long-run equilibrium by $0.0063 \%$. The estimates suggest 


\section{Ml Macrothink}

Business and Economic Research

ISSN 2162-4860

2016, Vol. 6, No. 2

that percentage increases in LRGDP and LEAP last year significantly increase the growth rate of the capital stock. ${ }^{6}$ Higher levels of output may generate more profits for investors and thus they are more willing to buy new capital, while a larger labor force may attract more capital to accommodate it. The adjustment coefficient of $\mathrm{D}(\mathrm{LEAP})$ is significantly negative and a $10 \%$ shock last year is corrected by $0.0012 \%$, while no independent variable in this equation is significant and the adjusted R-squared is $-3.4 \%$. The weak exogeneity tests in Table 6 impose zero restrictions on the adjustment coefficients of each equation and operate under the null hypothesis of exogeneity. D(LRGDP) and D(LX) are weakly exogenous, so they should be omitted from the left-hand side of the system and only included on the right-hand side. D(LK) and D(LEAP) are endogenous (see Asteriou and Hall, 2016).

Granger Block Causality tests in Table 7 are performed to further investigate the causal relationships. The tests examine all four equations and determine whether one or all variables can be excluded from each equation. Causality or precedence seems to exist from all the other variables to $\mathrm{D}(\mathrm{LRGDP})$. $\mathrm{D}(\mathrm{LRGDP})$ and $\mathrm{D}(\mathrm{LEAP})$ "cause" $\mathrm{D}(\mathrm{LK})$ while all the other variables as a group "cause" $\mathrm{D}(\mathrm{LK})$. It appears that $\mathrm{D}$ (LRGDP) may "reverse cause" $\mathrm{D}(\mathrm{LX})$ at the $10 \%$ level of significance, but the causality becomes insignificant in block tests with two lags.

Table 6. Exogeneity Test for Philippines

\begin{tabular}{|l|l|l|}
\hline$H_{0}:$ weakly exogenous variable & Chi-square statistics & Probability \\
\hline $\mathrm{D}(\mathrm{LRGDP}), \mathrm{A}(1,1)=0$ & 0.58 & 0.45 \\
\hline $\mathrm{D}(\mathrm{LK}), \mathrm{A}(2,1)=0$ & 4.54 & 0.03 \\
\hline $\mathrm{D}(\mathrm{LEAP}), \mathrm{A}(3,1)=0$ & 11.56 & 0.00067 \\
\hline $\mathrm{D}(\mathrm{LX}), \mathrm{A}(4,1)=0$ & 0.47 & 0.49 \\
\hline
\end{tabular}

Table 7. Block Causality Tests for Philippines

\begin{tabular}{|l|l|l|l|}
\hline Dependent variable: D(LRGDP) \\
\hline Excluded & Chi-sq & df & Prob. \\
\hline D(LK) & $6.1834^{* *}$ & 1 & 0.0129 \\
\hline D(LEAP) & $4.5172^{*}$ & 1 & 0.0336 \\
\hline D(LX) & $4.1312^{*}$ & 1 & 0.0421 \\
\hline All & $15.2667^{* *}$ & 3 & 0.0016 \\
\hline Dependent variable: D(LK) \\
\hline Excluded & Chi-sq & df & Prob. \\
\hline D(LRGDP) & $5.9922^{* *}$ & 1 & 0.0144 \\
\hline D(LEAP) & $5.1697^{*}$ & 1 & 0.0230 \\
\hline D(LX) & 0.1418 & 1 & 0.7065 \\
\hline All & $9.4801^{*}$ & 3 & 0.0235 \\
\hline Dependent variable: D(LEAP) \\
\hline Excluded & Chi-sq & df & Prob. \\
\hline
\end{tabular}

${ }^{6}$ Detailed results are available upon requests. 


\begin{tabular}{|l|l|l|l|}
\hline D(LRGDP) & 2.4139 & 1 & 0.1203 \\
\hline $\mathrm{D}(\mathrm{LK})$ & 0.9237 & 1 & 0.3365 \\
\hline $\mathrm{D}(\mathrm{LX})$ & 0.0504 & 1 & 0.8223 \\
\hline All & 2.6508 & 3 & 0.4487 \\
\hline
\end{tabular}

\begin{tabular}{|l|l|l|l|}
\hline \multicolumn{3}{|l|}{ Dependent variable: D(LX) } \\
\hline Excluded & Chi-sq & df & Prob. \\
\hline D(LRGDP) & 2.8877 & 1 & 0.0893 \\
\hline D(LK) & 1.0806 & 1 & 0.2986 \\
\hline D(LEAP) & 2.6325 & 1 & 0.1047 \\
\hline All & 4.9672 & 3 & 0.1742 \\
\hline
\end{tabular}

The impulse response function illustrates the direction and strength of the interactions among the variables. This study uses a generalized decomposition process first proposed by Pesaran and Shin (1998) that constructs an orthogonal set of innovations that does not depend on the VAR ordering. Figure 4 shows the responses of the four variables to a unitary shock in their own values and the other variables over a 10-year period. In light of Granger causality tests, the response of LRGDP to a standard deviation (SD) in LX is significantly positive and sustained. The responses of LRGDP to a SD in LK and LEAP are significantly positive but are smaller than its response to LX. The responses of LK to a SD in LRGDP and LEAP are at first significantly positive and then exhibit a tendency of levelling off, probably because a country cannot accommodate an infinite amount of capital as the economy flourishes and labor increases. Although not captured by the VECM and causality tests, the responses of LEAP to the other variables seem significantly positive and sustained. LX also responds to LRGDP positively. All variables respond positively to their past values except that LX drops off slightly at the beginning. For a developing country there may initially be some adjustment costs to participating in world trade such as income redistribution from non-exports to exports sectors, but exports eventually rise because of its outweighing benefits.

The impulse response function is roughly consistent with the VECM and Block causality tests, providing further evidence that exports promote economic output in the short run. There is weak evidence that economic output may "reverse cause" exports. The slightly odd results in the VECM may relate to the relatively low degrees of freedom. For example, just two endogenous variables with one lag can cost 6 degrees of freedom. 

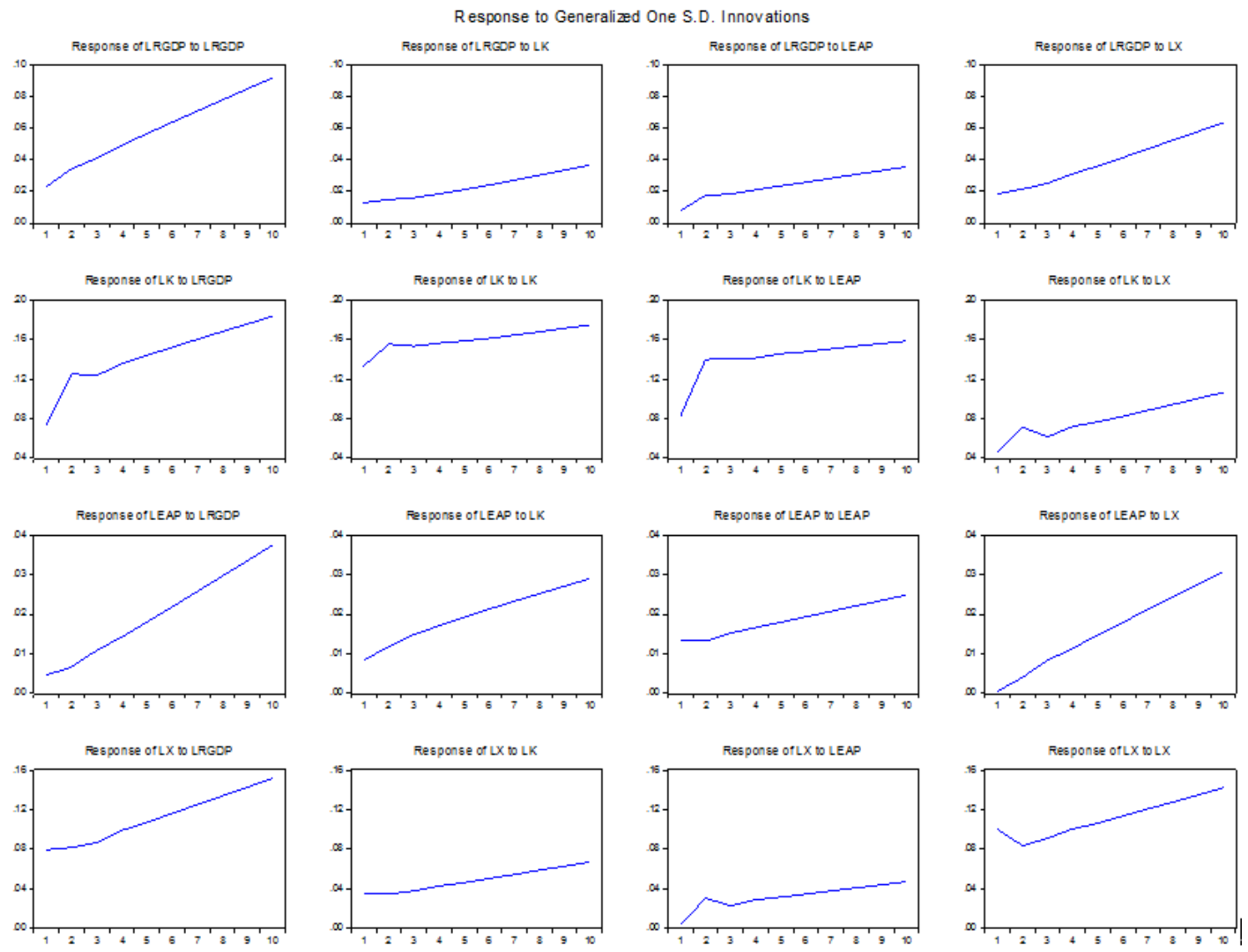

Figure 4. Impulse Response Functions for Philippines

\subsection{Singapore}

\subsubsection{Unit Root Tests and Johansen Cointegration}

All variables exhibit an upward trend in Figure 5 and may be non-stationary. In Table 8 the unit root tests return consistent results that LRGDP and LX are I(1). Only the KPSS test concludes that LK is stationary and LK is probably I(1) as the other tests suggest. The ADF and KPSS test find that LEAP is stationary but the PP tests find it I(1) and the Zivot-Andrews tests find it I(2). Singapore's labor force is unlikely to explode with an exponential trend. Figure 6 shows that the first difference of LEAP wanders up and down with little fluctuation. The Zivot-Andrews test of $\mathrm{D}(\mathrm{LEAP})$ cannot reject the null at $5 \%$ probably because a second break such as 1992 exists besides 2006. LEAP is probably I(1) as the more powerful PP test suggests.

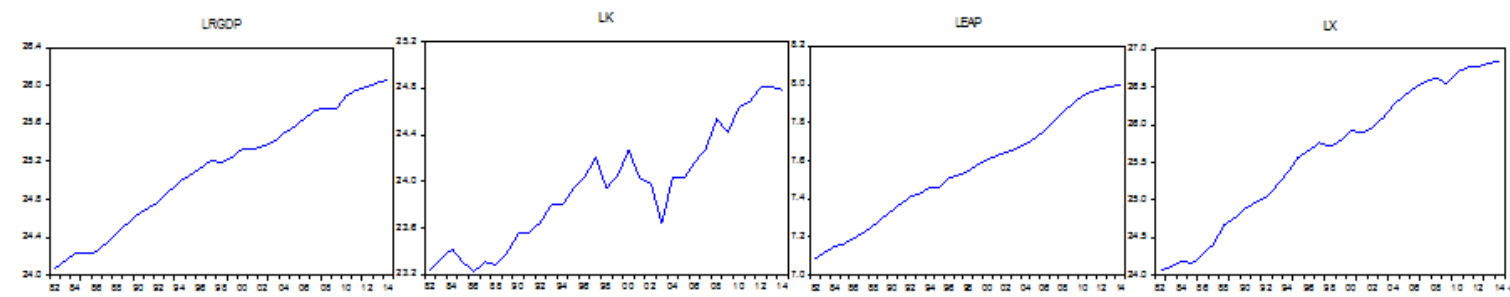

Figure 5. Plots of the Variables for Singapore (1982-2014) 
Table 8. Stationarity Tests for Singapore

\begin{tabular}{|l|l|l|l|l|l|l|l|l|}
\hline & \multicolumn{9}{|l|}{ Level data } & \multicolumn{4}{l|}{ First difference } \\
\cline { 2 - 8 } & ADF & PP & KPSS & ZA & ADF & PP & KPSS & ZA \\
\hline LRGDP & 8.72 & 8.30 & $0.15^{*}$ & -3.54 & $-4.91^{* *}$ & $-4.87^{* *}$ & 0.06 & $-5.83^{* *}$ \\
\hline LK & -2.74 & -2.66 & 0.07 & -4.60 & $-7.36^{* *}$ & $-7.38^{* *}$ & & $-8.06^{* *}$ \\
\hline LEAP & $-3.98^{*}$ & 9.77 & 0.08 & -3.37 & & $-3.59^{*}$ & & -3.28 \\
\hline LX & 6.53 & 6.53 & $0.17^{*}$ & -2.96 & $-4.86^{* *}$ & $-5.09^{* *}$ & 0.09 & $-5.41^{*}$ \\
\hline
\end{tabular}

$* 5 \%$ significance and $* * 1 \%$ significance.

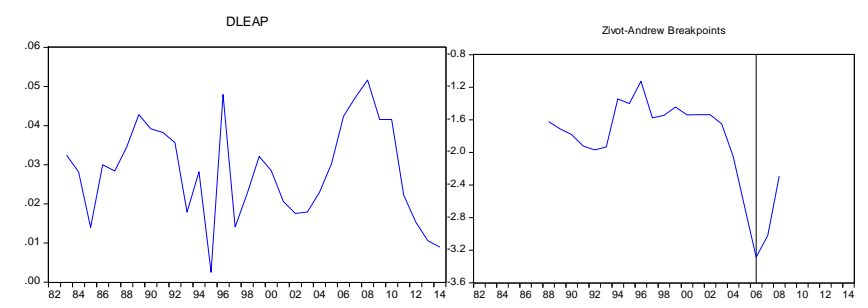

Figure 6. Zivot-Andrews test for LEAP

Similar to Philippines, the SBC criterion in Table 9 indicates that 1 lag is optimal. With the Pantula procedure both Max-Eigen and trace statistics in Table 10 select Model 3 which allows CE and VAR to drift around an intercept. The two statistics find a unique cointegrating vector so a VECM is generated in Table 11. The serial correlation LM tests and White heteroskedasticity tests indicate white-noise residuals. The cointegrating equation is normalized on LRGDP and the other three variables are significant at 5\% with the expected positive signs. In the long run exports promote economic output and seem to have a larger effect than capital.

Table 9. VAR Lag Criteria for Singapore

\begin{tabular}{|l|l|l|l|l|l|l|}
\hline Lag & LogL & LR & FPE & AIC & SC & HQ \\
\hline 0 & 99.09 & NA & $1.67 \mathrm{e}-08$ & -6.56 & -6.37 & -6.50 \\
\hline 1 & 242.56 & $237.47^{*}$ & $2.57 \mathrm{e}-12^{*}$ & $-15.35^{*}$ & $-14.41^{*}$ & $-15.05^{*}$ \\
\hline 2 & 253.07 & 14.49 & $4.03 \mathrm{e}-12$ & -14.97 & -13.27 & -14.44 \\
\hline 3 & 269.31 & 17.92 & $4.79 \mathrm{e}-12$ & -14.99 & -12.54 & -14.22 \\
\hline 4 & 290.10 & 17.20 & $5.20 \mathrm{e}-12$ & -15.32 & -12.11 & -14.31 \\
\hline
\end{tabular}

* indicates lag order selected by the criterion

Table 10. Johansen Tests for Singapore

\begin{tabular}{|c|c|c|c|c|c|c|c|}
\hline \multicolumn{4}{|c|}{ Trace statistics } & \multicolumn{4}{|c|}{ Max-Eigen statistics } \\
\hline Rank & Model 2 & Model 3 & Model 4 & Rank & Model 2 & Model 3 & Model 4 \\
\hline 0 & $70.87 *$ & $54.95^{*}$ & 60.31 & 0 & $41.60 *$ & $30.24 *$ & 30.78 \\
\hline 1 & 29.27 & 24.71 & 29.53 & 1 & 17.74 & 16.36 & 16.64 \\
\hline 2 & 11.52 & 8.35 & 12.89 & 2 & 6.72 & 4.97 & 8.05 \\
\hline
\end{tabular}


*indicates the statistic is significant at $5 \%$.

Table 11. VECM for Singapore

\begin{tabular}{|c|c|c|c|c|}
\hline \multicolumn{5}{|c|}{ Normalized Cointegration Coefficients } \\
\hline LRGDP & LK & LEAP & LX & C \\
\hline \multirow[t]{2}{*}{1.0000} & -0.0554 & -0.5518 & -0.4679 & -7.6543 \\
\hline & {$[-3.09]$} & {$[-10.06]$} & {$[-32.95]$} & \\
\hline \multicolumn{5}{|l|}{ Error Correction Table } \\
\hline & D(LRGDP) & $\mathrm{D}(\mathrm{LK})$ & $\mathrm{D}($ LEAP) & $\mathrm{D}(\mathrm{LX})$ \\
\hline Error correction coefficient & -1.1031 & 0.0781 & -0.5478 & -0.7152 \\
\hline t-statistics & {$[-2.12]$} & {$[0.038]$} & {$[-3.93]$} & {$[-0.70]$} \\
\hline R-squared & 0.3399 & 0.3338 & 0.5167 & 0.2554 \\
\hline Adj. R-squared & 0.2078 & 0.2006 & 0.4201 & 0.1065 \\
\hline Akaike AIC & -3.6426 & -0.9181 & -6.2756 & -2.2908 \\
\hline Schwarz SC & -3.3651 & -0.6406 & -5.9981 & -2.0133 \\
\hline
\end{tabular}

\subsubsection{Vector Error Correction Model}

Among the four variables $\mathrm{D}(\mathrm{LRGDP})$ and $\mathrm{D}(\mathrm{LEAP})$ show significant negative adjustment coefficients. It is surprising that the adjustment coefficient of D(LRGDP) is -1.1 and a $10 \%$ shock last year is "overcorrected" by $110 \%$. Only D(LK) is significant and a percentage increase in LK last year decreases LRGDP. For D(LEAP) a $10 \%$ shock last year is corrected by $55 \%$. No independent variable in this equation is significant and the adjusted R-squared is $42 \%$. The significant constants in the two equations suggest potential bias of omitted variables, but the results do not improve when the VECM is run with two lags. The weak exogeneity tests in Table 12 suggest that $\mathrm{D}(\mathrm{LK})$ and $\mathrm{D}(\mathrm{LX})$ are weakly exogenous. Granger Block Causality tests in Table 13 find precedence from $\mathrm{D}(\mathrm{LK})$ to $\mathrm{D}(\mathrm{LRGDP})$ and if tests are run with two lags the other variables as a group cause $\mathrm{D}(\mathrm{LRGDP}) \mathrm{D}(\mathrm{LK})$ and the other variables as a group cause $\mathrm{D}(\mathrm{LX})$, partly because an increase in capital enlarges the production capacity for exports.

Table 12. Exogeneity Test for Singapore

\begin{tabular}{|l|l|l|}
\hline$H_{0}:$ weakly exogenous variable & Chi-square statistics & Probability \\
\hline $\mathrm{D}(\mathrm{LRGDP}), \mathrm{A}(1,1)=0$ & 4.21 & 0.04 \\
\hline $\mathrm{D}(\mathrm{LK}), \mathrm{A}(2,1)=0$ & 0.0017 & 0.97 \\
\hline $\mathrm{D}(\mathrm{LEAP}), \mathrm{A}(3,1)=0$ & 10.12 & 0.0015 \\
\hline $\mathrm{D}(\mathrm{LX}), \mathrm{A}(4,1)=0$ & 0.40 & 0.53 \\
\hline
\end{tabular}

Table 13. Block Causality Tests for Singapore

\begin{tabular}{|l|l|l|l|}
\hline \multicolumn{4}{|l|}{ Dependent variable: D(LRGDP) } \\
\hline Excluded & Chi-sq & df & Prob. \\
\hline D $($ LK $)$ & $7.3218^{* *}$ & 1 & 0.0068 \\
\hline D(LEAP) & 0.3281 & 1 & 0.5668 \\
\hline
\end{tabular}




\begin{tabular}{|c|c|c|c|}
\hline $\mathrm{D}(\mathrm{LX})$ & 0.4175 & 1 & 0.5182 \\
\hline All & $7.4054 *$ & 3 & 0.0600 \\
\hline \multicolumn{4}{|c|}{ Dependent variable: $\mathrm{D}(\mathrm{LK})$} \\
\hline Excluded & Chi-sq & \multicolumn{2}{|c|}{ df Prob. } \\
\hline D(LRGDP) & 0.1531 & 1 & 0.6956 \\
\hline D(LEAP) & 2.3652 & 1 & 0.1241 \\
\hline $\mathrm{D}(\mathrm{LX})$ & 0.2292 & 1 & 0.6321 \\
\hline All & 6.3553 & 3 & 0.0955 \\
\hline \multicolumn{4}{|c|}{ Dependent variable: D(LEAP) } \\
\hline Excluded & Chi-sq & \multicolumn{2}{|c|}{ df Prob. } \\
\hline D(LRGDP) & 0.9801 & 1 & 0.3222 \\
\hline $\mathrm{D}(\mathrm{LK})$ & 0.0825 & 1 & 0.7740 \\
\hline $\mathrm{D}(\mathrm{LX})$ & 1.2252 & 1 & 0.2683 \\
\hline All & 1.2318 & 3 & 0.7454 \\
\hline \multicolumn{4}{|c|}{ Dependent variable: $\mathrm{D}(\mathrm{LX})$} \\
\hline Excluded & Chi-sq & \multicolumn{2}{|c|}{\begin{tabular}{l|l} 
df & Prob. \\
\end{tabular}} \\
\hline D(LRGDP) & 1.4329 & 1 & 0.2313 \\
\hline $\mathrm{D}(\mathrm{LK})$ & $7.5810^{* *}$ & 1 & 0.0059 \\
\hline $\mathrm{D}($ LEAP) & 0.2586 & 1 & 0.6111 \\
\hline All & $7.7947 *$ & 3 & 0.0504 \\
\hline
\end{tabular}

The impulse response functions are run, again, with a generalized decomposition process in Figure 7. In the light of Granger causality tests, the response of LRGDP to a SD in LK is negative for about 5 years and the response of LRGDP to LEAP is slightly positive. The response of LRGDP to a SD in LX is significantly positive for 6 years and then levels off, while LK and LEAP also have levelling-off responses to LX. The response of LEAP to the other variables is extremely weak. It is surprising that the response of LX to LK and LEAP is negative for 2 to 3 years. LEAP and LX respond positively to their past values but LK responds negatively probably due to the effects of diminishing returns to scale. The impulse response functions are roughly consistent with the VECM and causality tests. There is evidence that exports promote economic output in the short run and the reverse causation is much weaker. 

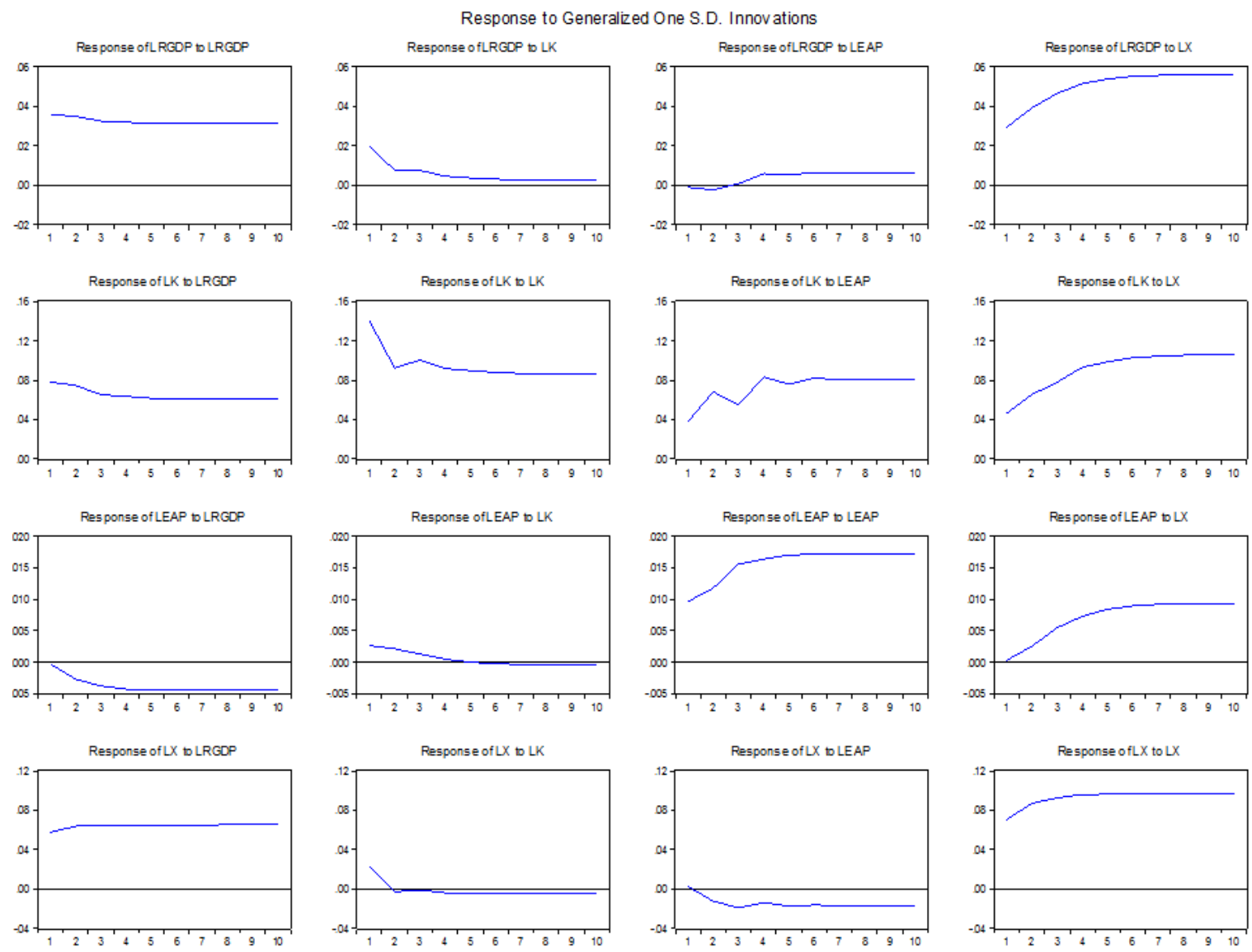

Figure 7. Impulse Response Functions for Singapore

\subsection{India}

Figure 8 shows that all variables have upward trends and may not be stationary. In Table 14 the four unit root tests generate consistent results that LK and LX are I(1). The KPSS tests find that LRGDP is I(2) but all other tests, including the most conservative Zivot-Andrews test, reject the null hypothesis that D(LRGDP) has a unit root at the $1 \%$ level. The ADF and PP tests find that LEAP is I(2) while the KPSS and ZA tests find it to be I(1). The plot of LEAP shows no evidence of an exponential trend even though India is populous. The preponderance of the evidence suggests that LRGDP and LEAP are probably I(1).

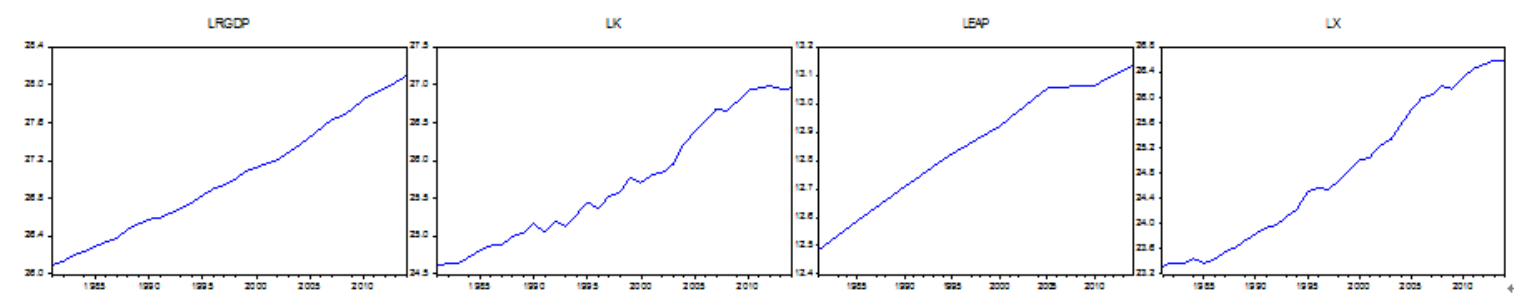

Figure 8. Plots of the Variables for India (1981-2014) 
Table 14. Stationarity Tests for India

\begin{tabular}{|l|l|l|l|l|l|l|l|l|}
\hline & \multicolumn{4}{|l|}{ Level data } & \multicolumn{4}{l|}{ First difference } \\
\cline { 2 - 9 } & ADF & PP & KPSS & ZA & ADF & PP & KPSS & ZA \\
\hline LRGDP & 16.97 & 16.22 & $0.20^{*}$ & -3.45 & $-5.47^{* *}$ & $-6.39^{* *}$ & $0.16^{*}$ & $-6.12^{* *}$ \\
\hline LK & -2.18 & -2.09 & $0.17^{*}$ & -3.81 & $-6.91^{* *}$ & $-6.91^{* *}$ & 0.11 & $-10.57^{* *}$ \\
\hline LEAP & 2.95 & -2.63 & $0.18^{*}$ & -5.03 & -1.91 & -0.94 & 0.06 & $-7.35^{* *}$ \\
\hline LX & -2.74 & -2.75 & $0.16^{*}$ & -2.94 & $-4.72^{* *}$ & $-4.70^{* *}$ & 0.29 & $-6.45^{* *}$ \\
\hline
\end{tabular}

$* 5 \%$ significance and $* * 1 \%$ significance.

The SBC criterion in Table 15 indicates that 1 lag is optimal. With the Pantula procedure the Max-Eigen statistics in Table 16 select Model 4 that has an intercept and linear trend in CE. Table 17 shows the two cointegrating vectors for Model 4 in which the trends are both significant. Appealing to economic theory, the paper chooses the equation normalized on LRGDP as the long-run equilibrium. LK and LX are significant at the 5\% while LK may be weakly exogenous since its adjustment coefficient is insignificant. In the long run capital promotes economic output but it is unexpected that exports hinder economic output. The coefficient of LX is much smaller than that of LK in absolute value.

It is difficult to interpret the VECM with two estimated cointegrating equations since the researcher has to relate them to theoretical ones that lie behind the data (the so-called identification problem in cointegrated systems), so the paper runs Granger causality tests in level form (see Asteriou and Hall, 2016). Table 18 indicates an unsurprising bi-directional causality between LK and LEAP. LX causes LK perhaps because profitability in exports attracts capital investments from home and abroad. LEAP causes LX probably because a larger active population lowers unit labor costs and gives India a comparative advantage in world trade. It may appear that LRGDP causes LK and LX causes LEAP since their p-values are only slightly greater than 0.05 , but the causality becomes insignificant when the tests are performed with two or three lags. No significant causality exists between exports and economic output.

Table 15. VAR Lag Criteria for India

\begin{tabular}{|c|c|c|c|c|c|c|}
\hline Lag & $\operatorname{LogL}$ & LR & FPE & AIC & SC & HQ \\
\hline 0 & 103.58 & NA & $1.54 \mathrm{e}-08$ & -6.64 & -6.45 & -6.58 \\
\hline 1 & 291.44 & 313.10 & $1.65 \mathrm{e}-13$ & -18.10 & $-17.16 *$ & -17.80 \\
\hline 2 & 315.62 & $33.86 *$ & $1.02 \mathrm{e}-13 *$ & -18.64 & -16.96 & $-18.10^{*}$ \\
\hline 3 & 330.98 & 17.41 & $1.26 \mathrm{e}-13$ & -18.60 & -16.17 & -17.82 \\
\hline 4 & 351.87 & 18.10 & $1.30 \mathrm{e}-13$ & $-18.92 *$ & -15.75 & -17.91 \\
\hline
\end{tabular}

* indicates lag order selected by the criterion 
Table 16. Johansen Tests for India

\begin{tabular}{|c|c|c|c|c|c|c|c|}
\hline \multicolumn{4}{|c|}{ Trace statistics } & \multicolumn{4}{|c|}{ Max-Eigen statistics } \\
\hline Rank & Model 2 & Model 3 & Model 4 & Rank & Model 2 & Model 3 & Model 4 \\
\hline 0 & $84.61 *$ & $59.32 *$ & $86.16^{*}$ & 0 & $45.95 *$ & $32.07 *$ & $39.07 *$ \\
\hline 1 & $38.66^{*}$ & 27.25 & $47.09 *$ & 1 & 17.13 & 16.98 & $28.96 *$ \\
\hline 2 & $21.53^{*}$ & 10.27 & 18.13 & 2 & 13.62 & 8.11 & 10.06 \\
\hline
\end{tabular}

*indicates the statistic is significant at $5 \%$.

Table 17. Two Cointegrating Vectors for Model 4

\begin{tabular}{|l|l|l|l|l|}
\hline \multicolumn{5}{|c|}{ Normalized cointegrating coefficients [t-statistics] } \\
\hline LRGDP & LEAP & LK & LX & $@$ TREND(82) \\
\hline 1.0000 & 0.0000 & -0.3346 & 0.0956 & -0.0464 \\
\hline & & {$[7.83]$} & {$[2.60]$} & {$[17.24]$} \\
\hline 0.0000 & 1.0000 & 0.1449 & -0.040756 & -0.026097 \\
\hline & & {$[4.93]$} & {$[1.61]$} & {$[17.11]$} \\
\hline
\end{tabular}

Table 18. Granger Causality tests for India

\begin{tabular}{|c|c|c|c|}
\hline Null Hypothesis: & Obs & F-Statistic & Prob. \\
\hline LK does not Granger Cause LRGDP & \multirow[t]{2}{*}{33} & 0.0872 & 0.7698 \\
\hline LRGDP does not Granger Cause LK & & 3.3226 & 0.0783 \\
\hline LEAP does not Granger Cause LRGDP & \multirow[t]{2}{*}{33} & 1.8116 & 0.1884 \\
\hline LRGDP does not Granger Cause LEAP & & 1.1197 & 0.2984 \\
\hline LX does not Granger Cause LRGDP & \multirow[t]{2}{*}{33} & 2.5631 & 0.1199 \\
\hline LRGDP does not Granger Cause LX & & 2.3069 & 0.1393 \\
\hline LEAP does not Granger Cause LK & \multirow[t]{2}{*}{33} & $6.3410^{*}$ & 0.0174 \\
\hline LK does not Granger Cause LEAP & & $5.6343 *$ & 0.0242 \\
\hline LX does not Granger Cause LK & \multirow[t]{2}{*}{33} & $8.6951 * *$ & 0.0061 \\
\hline LK does not Granger Cause LX & & 0.7415 & 0.3960 \\
\hline LX does not Granger Cause LEAP & \multirow[t]{2}{*}{33} & 3.6689 & 0.0650 \\
\hline LEAP does not Granger Cause LX & & $13.5354 * *$ & 0.0009 \\
\hline
\end{tabular}

\subsection{Thailand}

Figure 9 below shows that all variables have upward trends although LK has more variation. In Table 19 the unit root tests only return one consistent result that LX is I(1). The ADF and PP tests find LK I(1) while the KPSS and conservative Zivot-Andrews tests find it stationary, so LK is probably I(1). The Zivot-Andrews tests can reject the null hypothesis at the $10 \%$ but not at the 5\% for the level variables of LRGDP and LEAP, while the tests cannot reject the null at $5 \%$ for their first differences. LRGDP and LEAP are I(1) in the ADF and PP tests. The KPSS test finds LRGDP I(1) and LEAP I(0). Figure 10 illustrates that D(LRGDP) and $\mathrm{D}($ LEAP) do not have exponential trends but may suffer from over one break, so the two variables are probably I(1). 


\section{Macrothink}

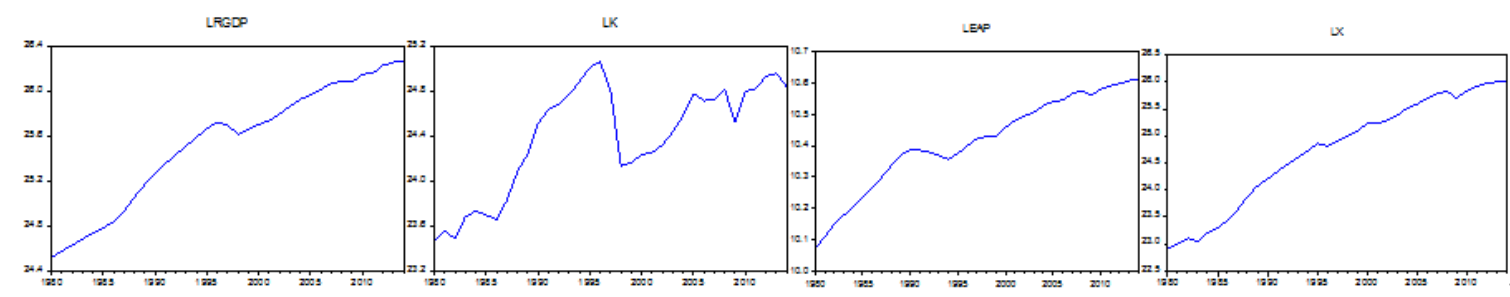

Figure 9. Plots of the Variables for Thailand (1980-2014)

Table 19. Stationarity Tests for Thailand

\begin{tabular}{|l|l|l|l|l|l|l|l|l|}
\hline & \multicolumn{4}{|l|}{ Level data } & \multicolumn{4}{l|}{ First difference } \\
\cline { 2 - 9 } & ADF & PP & KPSS & ZA & ADF & PP & KPSS & ZA \\
\hline LRGDP & 2.20 & -2.01 & $0.18^{*}$ & -4.84 & $-3.00^{*}$ & $-3.01^{*}$ & 0.07 & -4.15 \\
\hline LK & 1.28 & 1.16 & 0.12 & $-5.31 * *$ & $-4.38^{* *}$ & $-4.39^{* *}$ & & \\
\hline LEAP & -2.75 & -2.82 & 0.13 & -3.79 & $-2.29 *$ & $-2.99 *$ & & -5.00 \\
\hline LX & -2.38 & -2.33 & $0.19 *$ & -2.74 & $-5.33^{* *}$ & $-5.33^{* *}$ & 0.09 & $-7.03^{* *}$ \\
\hline
\end{tabular}

$* 5 \%$ significance and $* * 1 \%$ significance.

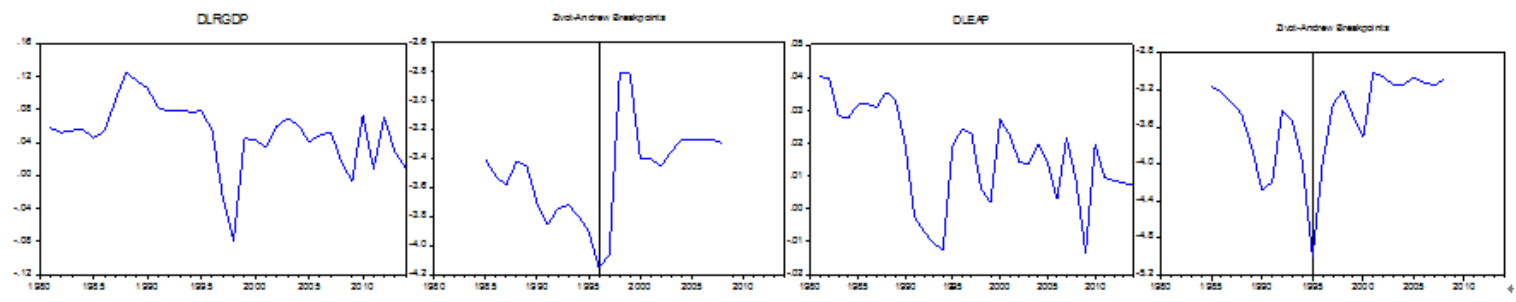

Figure 10. Zivot-Andrews test for LRGDP and LEAP

The SBC criterion in Table 20 indicates that two lags are optimal. Following the Pantula procedure, the Max-Eigen statistics in Table 21 select model 2 with an intercept in the CE. Trace statistics, however, find three cointegrating vectors for each model. It is surprising to have so many potential long-run equilibria. Table 22 shows the three estimated cointegrating vectors for Model 2. In terms of statistical significance and economic theory, the paper chooses to interpret the equation normalized on LRGDP. The long-run estimate for LX is significantly positive and LX may be weakly exogenous since its adjustment coefficient is insignificant. The significant constant may suggest omitted variables. The pairwise causality tests in Table 23 find bi-directional causality between LK and LRGDP partly because a better economy attracts more capital investments to accommodate the growing demand. LEAP and LX also cause LRGDP, which verifies the causality from all inputs of the modified aggregate production function. LEAP causes LK and LX, similar to the case of India. There is strong evidence that exports promote economic output and not the other way around.

Table 20. VAR Lag Criteria for Thailand

\begin{tabular}{|l|l|l|l|l|l|l|}
\hline Lag & LogL & LR & FPE & AIC & SC & HQ \\
\hline 0 & 93.46 & NA & $3.66 \mathrm{e}-08$ & -5.77 & -5.59 & -5.71 \\
\hline
\end{tabular}




\begin{tabular}{|l|l|l|l|l|l|}
\hline 1 & 252.40266 .61 & $3.66 \mathrm{e}-12$ & -14.99 & -14.07 & -14.69 \\
\hline 2 & $284.8246 .01 *$ & $1.34 \mathrm{e}-12$ & -16.05 & $-14.39 *$ & $-15.51 *$ \\
\hline 3 & 303.4421 .63 & $1.32 \mathrm{e}-12 *$ & $-16.22 *$ & -13.82 & -15.44 \\
\hline 4 & 316.4511 .75 & $2.21 \mathrm{e}-12$ & -16.03 & -12.88 & -15.00 \\
\hline
\end{tabular}

* indicates lag order selected by the criterion

Table 21. Johansen Tests for Thailand

\begin{tabular}{|c|c|c|c|c|c|c|c|}
\hline \multicolumn{4}{|c|}{ Trace statistics } & \multicolumn{4}{|c|}{ Max-Eigen statistics } \\
\hline Rank & Model 2 & Model 3 & Model 4 & Rank & Model 2 & Model 3 & Model 4 \\
\hline 0 & $83.61^{*}$ & $73.05^{*}$ & $96.73 *$ & 0 & $32.38^{*}$ & $32.34 *$ & $37.73^{*}$ \\
\hline 1 & $51.23 *$ & $40.72 *$ & $59.00^{*}$ & 1 & $22.87 *$ & 18.00 & $32.33 *$ \\
\hline 2 & $28.35^{*}$ & $22.71^{*}$ & $26.67 *$ & 2 & $17.73^{*}$ & 13.13 & 15.42 \\
\hline
\end{tabular}

*indicates the statistic is significant at $5 \%$.

Table 22. Three Cointegrating Vectors for Model 2

\begin{tabular}{|l|l|l|l|l|}
\hline \multicolumn{5}{|c|}{ Normalized cointegrating coefficients [t-statistics] } \\
\hline LRGDP & LK & LEAP & LX & C \\
\hline 1.0000 & 0.0000 & 0.0000 & -2.0790 & 31.8455 \\
\hline & & & {$[4.54]$} & {$[2.60]$} \\
\hline 0.0000 & 1.0000 & 0.0000 & -4.6877 & 108.4041 \\
\hline & & & {$[3.63]$} & {$[3.14]$} \\
\hline 0.0000 & 0.0000 & 1.0000 & -0.4608 & 2.1835 \\
\hline & & & {$[5.17]$} & {$[0.92]$} \\
\hline
\end{tabular}

Table 23. Granger Causality tests for Thailand

\begin{tabular}{|c|c|c|c|}
\hline Null Hypothesis: & Obs & F-Statistic & Prob. \\
\hline LK does not Granger Cause LRGDP & \multirow[t]{2}{*}{33} & $4.2647 *$ & 0.0242 \\
\hline LRGDP does not Granger Cause LK & & $11.8398 * *$ & 0.0002 \\
\hline LEAP does not Granger Cause LRGDP & \multirow{2}{*}{$\begin{array}{lll}\mathrm{P} & 33 \\
\mathrm{P} & \end{array}$} & $10.2551 * *$ & 0.0005 \\
\hline LRGDP does not Granger Cause LEAP & & 0.3156 & 0.7319 \\
\hline LX does not Granger Cause LRGDP & \multirow[t]{2}{*}{33} & $3.2125^{*}$ & 0.0555 \\
\hline LRGDP does not Granger Cause LX & & 0.5619 & 0.5764 \\
\hline LEAP does not Granger Cause LK & \multirow[t]{2}{*}{33} & $5.4219 * *$ & 0.0102 \\
\hline LK does not Granger Cause LEAP & & 1.2905 & 0.2910 \\
\hline LX does not Granger Cause LK & \multirow[t]{2}{*}{33} & 1.2804 & 0.2937 \\
\hline LK does not Granger Cause LX & & 0.0547 & 0.9469 \\
\hline LX does not Granger Cause LEAP & \multirow[t]{2}{*}{33} & 0.8622 & 0.4332 \\
\hline LEAP does not Granger Cause LX & & $5.2681 * *$ & 0.0114 \\
\hline
\end{tabular}

\subsection{China}

Figure 11 shows that all variables except LEAP rise very rapidly over time. In Table 24 the 
unit root tests return mixed results for every variable, as the power of the tests may fall given the relatively low degrees of freedom. The PP and Zivot-Andrews tests find that LRGDP is $\mathrm{I}(2)$ while the ADF and KPSS tests find it I(0). The ADF and PP tests find that LK is I(1) while the Zivot-Andrews test finds it I(2). The KPSS and Zivot-Andrews tests find that LEAP is $\mathrm{I}(2)$ while the PP test finds it $\mathrm{I}(0)$. LRGDP is probably $\mathrm{I}(2)$ and the other variables $\mathrm{I}(1)$. Cointegration does not exist when there are three I(1) and one I(2) variables (see Harris, 1995). Without cointegration no "causality" can be established. The data and estimation problems prevent the further investigation of the Chinese case.

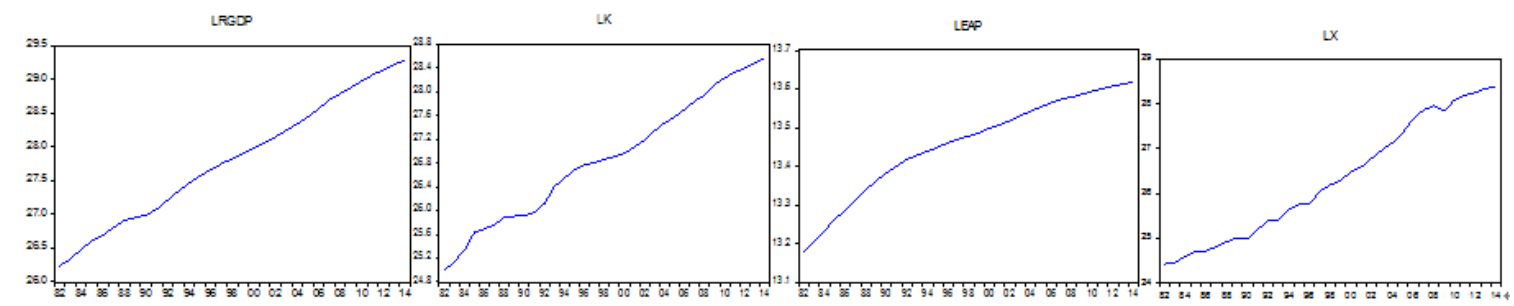

Figure 11. Plots of the Variables for China (1982-2014)

Table 24. Stationarity Tests for China

\begin{tabular}{|l|l|l|l|l|l|l|l|l|}
\hline & \multicolumn{4}{|l|}{ Level data } & \multicolumn{4}{l|}{ First difference } \\
\cline { 2 - 9 } & ADF & PP & KPSS & ZA & ADF & PP & KPSS & ZA \\
\hline LRGDP & $-4.72^{* *}$ & -2.07 & 0.09 & -5.06 & & -2.57 & & -4.72 \\
\hline LK & -3.45 & -2.77 & 0.07 & -4.39 & $-3.66^{*}$ & $-3.65^{*}$ & & -4.66 \\
\hline LEAP & -3.03 & $-3.85^{*}$ & $0.19^{*}$ & -3.66 & $-2.56^{*}$ & & $0.15^{*}$ & -3.75 \\
\hline LX & -2.23 & -2.25 & 0.14 & -2.59 & $-5.60^{* *}$ & $-5.60^{* *}$ & & $-7.90^{* *}$ \\
\hline
\end{tabular}

$* 5 \%$ significance and $* * 1 \%$ significance.

\section{Conclusion}

Johansen cointegration tests find a positive long-run relationship between exports and economic output for Philippines, Singapore, and Thailand. Cointegration tests find a negative long-run relationship between exports and economic output for India. The Block causality tests and impulse response functions for Philippines and Singapore find stronger causality from exports to economic output rather than the reverse. Granger causality tests in level form also find significant causality from exports to economic output. No causality exists between exports and economic output in the case of India. Exports seem to promote economic growth in three of the four countries that have cointegrated data, which supports the exports-led growth hypothesis found in the extant literature, including Vohra's seminal paper.

The major limitation of this study is the relatively low degrees of freedom which may affect the power of conventional unit root and cointegration tests-despite the relatively long time span - and thus may explain some of the unusual VECM estimates. Future studies with more readily available data should also explore the linkages between export composition and economic growth in a larger sample of countries to make more compelling arguments. Still, this study represents a positive and significant contribution to the extant literature by 
extending the data set and applying more sophisticated econometric methodology to previous analyses of the validity of the export-led growth hypothesis for the countries under review.

From a policy standpoint, the results suggest that, for the countries in question, export-promotion policies (not prohibited under current WTO rules) such as export insurance and duty drawback (rebates for taxes paid on imported inputs) schemes should be strengthened and maintained by national and multilateral institutions (Mah, 2011).

\section{References}

Asteriou, D., \& S. G. Hall (2016). Applied Econometrics, $3^{\text {rd }}$ ed. New York: Palgrave Macmillan.

Awokuse, T. O. (2005). Exports, economic growth and causality in Korea. Applied Economics Letters, 12(11), 693-696. http://dx.doi.org/10.1080/13504850500188265

Balassa, B. (1985). Exports, policy choices, and economic growth in developing countries after the 1973 oil shock. Journal of Development Economics, 18(1), 23-35. http://dx.doi.org/10.1016/0304-3878(85)90004-5

Charemza, W. W., \& Deadman, D. F. (1997). New Directions in Econometric Practice: General to Specific Modelling, Cointegration and Vector Autoregression. Cheltenham, UK: Edward Elgar Publishers.

Chow, P. C. (1987). Causality between export growth and industrial development: empirical evidence from the NICs. Journal of Development Economics, 26(1), 55-63. http://dx.doi.org/10.1016/0304-3878(87)90051-4

Doldado, J. J., Jenkinson, T., \& Sosvilla-Rivero, S. (1990). Cointegration and unit roots. $\begin{array}{llll}\text { Journal of } & \text { Economic } & \text { Surveys, } & 4(3),\end{array}$ http://dx.doi.org/10.1111/j.1467-6419.1990.tb00088.x

Feder, G. (1983). On exports and economic growth. Journal of Development Economics, 12, 59-73. http://dx.doi.org/10.1016/0304-3878(83)90031-7

Ghatak, S., Milner, C., \& Utkulu, U. (1997). Exports, export composition and growth: cointegration and causality evidence for Malaysia. Applied Economics, 29(2), 213-223. http://dx.doi.org/10.1080/000368497327272

Granger, C. W. (1969). Investigating causal relations by econometric models and cross-spectral methods. Econometrica: Journal of the Econometric Society, 424-438. http://dx.doi.org/10.2307/1912791

Harris, R. (1995). Using Cointegration Analysis in Econometric Modelling. New York: Prentice-Hall.

Islam, M. N. (1998). Export expansion and economic growth: testing for cointegration and causality. Applied Economics, 30(3), 415-425. http://dx.doi.org/10.1080/000368498325930

Johansen, S., \& Juselius, K. (1990). Maximum likelihood estimation and inference on 
cointegration-with applications to the demand for money. Oxford Bulletin of Economics and Statistics, 52(2), 169-210. http://dx.doi.org/10.1111/j.1468-0084.1990.mp52002003.x

Koh, S. R., \& Mah, J. S. (2013). The effect of export composition on economic growth: the case of Korea. The Journal of Developing Areas, 47(1), 171-179. http://dx.doi.org/10.1353/jda.2013.0020

Maddala, G.S. \& In-Moo Kim (1998). Unit Roots, Cointegration, and Structural Change. New York: Cambridge University Press.

Mah, J. S. (2007). Economic growth, exports and export composition in China. Applied Economics Letters, 14(10), 749-752. http://dx.doi.org/10.1080/1350485042000314343

Mah , J. S. (2011). Export promotion policies, export composition and economic development of Korea. The Law and Development Review, 4(2), 1-27.

Pesaran, M.H., \& Shin, Y. (1998). Generalized impulse response analysis in linear $\begin{array}{lllll}\text { multivariate } \quad \text { models. } & \text { Economic }\end{array}$ http://dx.doi.org/10.1016/S0165-1765(97)00214-0

Perkins, D. H., Radelet, S., Lindauer, D. L., \& Steven, A. (2013). Economics of Development. Norton.

Phillips, P. C., \& Perron, P. (1988). Testing for a unit root in time series regression. Biometrika, 75(2), 335-346. http://dx.doi.org/10.1093/biomet/75.2.335

Ram, R. (1987). Exports and economic growth in developing countries: evidence from time-series and cross-section data. Economic Development and Cultural Change, 36(1), 51-72. Retrieved from http://www.jstor.org/stable/1153992

Sen, A. (2003). On unit-root tests when the alternative is a trend-break stationary process, Journal of Business and Economic Statistics, 21, 174-184. http://dx.doi.org/10.1198/073500102288618874

Sengupta, J. K., \& Espana, J. R. (1994). Exports and economic growth in Asian NICs: an econometric analysis for Korea. Applied Economics, 26(1), 41-51. http://dx.doi.org/10.1080/00036849400000060

Shin, Y., \& Schmidt, P. (1992). The KPSS stationarity test as a unit root test. Economics Letters, 38(4), 387-392. http://dx.doi.org/10.1016/0165-1765(92)90023-R

Thornton, J. (1996). Cointegration, causality and export-led growth in Mexico, 1895-1992. Economics Letters, 50(3), 413-416. http://dx.doi.org/10.1016/0165-1765(95)00780-6

Vohra, R. (2001). Export and economic growth: Further time series evidence from less-developed countries. International Advances in Economic Research, 7(3), 345-350. http://dx.doi.org/10.1007/BF02295403

Zivot, E., \& Andrews, D. W. (1992). Further evidence on the great crash, the oil-price shock, and the unit-root. Journal of Business \& Economic Statistics, 10(0), 3. http://dx.doi.org/ 
$10.1198 / 073500102753410372$

\section{Copyright Disclaimer}

Copyright for this article is retained by the author(s), with first publication rights granted to the journal.

This is an open-access article distributed under the terms and conditions of the Creative Commons Attribution license (http://creativecommons.org/licenses/by/3.0/). 